\title{
IMPORTS AND EXPORTS OF SERVICES: A SIMULTANEOUS DROP ${ }^{1}$
}

\author{
A.Firanchuk
}

From Q4 2014, Russian exports and imports of services have demonstrated a nearly simultaneous decrease (against the 2013 indices) which is largely in line with the dynamics of trade turnover. In Q1 2016, the decrease continued.

A review of Russia's foreign trade without the analysis of trade in services is incomplete. So, on the basis of the 2015 results that trade volume amounted to $\$ 140 \mathrm{bn}$ and rose to $21.0 \%$ of the total foreign trade turnover of goods and services ( $\$ 666 \mathrm{bn}$ ) as compared to $19.1 \%$ in 2013 . The share of services in the total imports of goods and services increased even further to $32.7 \%$ against $28.9 \%$ in 2013 . This is evidence of a stable and prominent share of services in the total foreign trade turnover and, particularly, Russia's imports.

Depreciation of the ruble exchange rate due to a drop in oil prices and Russian economic recession undoubtedly had an adverse effect on imports both of goods and services. It is to be noted that the data point to virtually similar dynamics of imports of services and imports of goods ${ }^{2}$. It means that imports of services and imports of goods responded almost in a similar way to macroeconomic changes.

A nearly twofold reduction of imports of building services which took place in the 2013-2015 period is largely similar to a dramatic decrease in imports of investment goods and durable goods. Introduction of sanctions against Turkish building companies in November 2015 is likely to result in a further drop in imports of building services in 2016.

It is to be noted that "telecommunication, computer and information services" happened to be the most stable ones as regards both imports and exports. A decrease in the above services was the minimum, while imports of the building sector's services fell dramatically. "Trips" remained the main item of imports of services with a $40 \%$ share.

In 2015, member-states of the Eurasian Economic Union and Asia-Pacific Economic Cooperation (APEC) increased their share in Russia's foreign trade in services to $5.1 \%$ (0.8 p.p.) and $12.9 \%$ (0.5 p.p.), respectively, mainly at the expense of Kazakhstan and China. The share of Ukraine fell considerably to $2.0 \%$ (0.4 p.p.) due to a drop in imports of services. The EU retained the position of Russia's important trade partner despite a 1.6 p.p. decrease in its share to $43.1 \%$. Russia's foreign trade in services with all important partners fell, except for Kazakhstan.

\section{Dynamics of Exports and Imports of Services}

As was stated above, from Q4 2014 exports and imports of services have been falling almost simultaneously (Fig. 1) which fact points to similarity of

1 This paper was originally published in Online Monitoring of Russia's Economic Outlook No.8(26).

2 For more information, see A. Knobel and A. Firanchuk. Foreign Trade: A Drop in Exports Justified a Decrease in the Trade Surplus. Russian Economic Developments. 2016, No.5, pp. 35-37. 


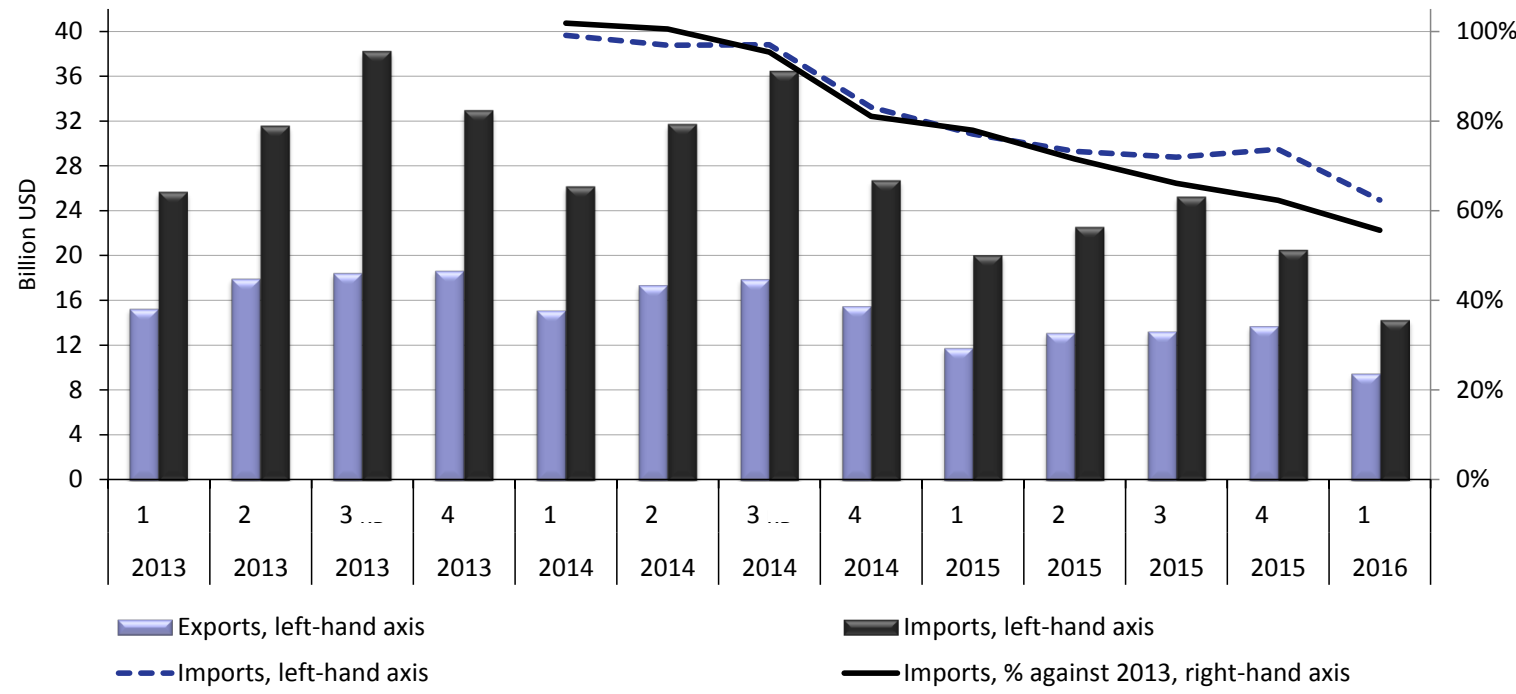

Source: The authors' calculations on the basis of the data of the Central Bank of Russia.

Fig. 1. Dynamics of Russian foreign trade in services

factors affecting trade in goods and services ${ }^{1}$. The services trade balance improved somewhat from -\$46.6bn in 2013 to -\$36.6bn in 2015.

In H2 2015, exports of services stabilized to some extent and then fell dramatically in Q1 2016 to amount to \$14.3bn (62.4\% against the 2013 index). Simultaneously, within the same period imports of services amounted to \$9.5bn (55.6\% against the 2013 index) - all those data differ insignificantly from similar relative changes in the turnover of goods in the same period ${ }^{2}$.

Prices in such sectors as "trips", "transport services", "other business services" and other sectors of the economy are often denominated in rubles. So, with depreciation of the ruble exchange rate prices of exports of services fell, while changes in demand on exports of services failed to make up for a drop in prices in US dollars. The above explains a decrease in the monetary volumes of exports of services denominated in US dollars.

\section{The Pattern of Imports and Exports in Services}

A decrease in import volumes was registered in all the prominent sectors of services, though it was erratic. So, in 2015 import volumes in various services sectors were decreasing unevenly and as compared to the 2013 base year lost from $9 \%$ to $48 \%$, which situation could not, but affect the pattern of Russian imports of services (Fig. 2). The smallest drop (9.2\%) took place in the "telecommunication, computer and information services" sector whose share rose from $4.7 \%$ in 2013 to $6.2 \%$ in 2015 . The largest drop (48.4\%) was registered in the "building" sector whose share fell from $7.3 \%$ to $5.5 \%$. In 2015 , the "trips" service sector which is the largest one as regards imports volumes fell by $34.9 \%$ (as compared to 2013 ) to $\$ 34.9 \mathrm{bn}$, while its share decreased insignificantly from $41.6 \%$ in 2013 to $39.5 \%$ in 2015 . It is worth mentioning growth in the share of "other business services" sector from

1 See also A Knobel. The Pattern and Prices on Individual Commodities of the Russian Exports and Imports. Russian Economic Developments. 2016, No.1, pp. 44-47.

2 For more information, see A.Knobel and A. Firanchyuk. Foreign Trade: A Drop in Exports Justified a Decrease in the Trade Surplus. Russian Economic Developments. 2016, No.5, pp. 35-37. 


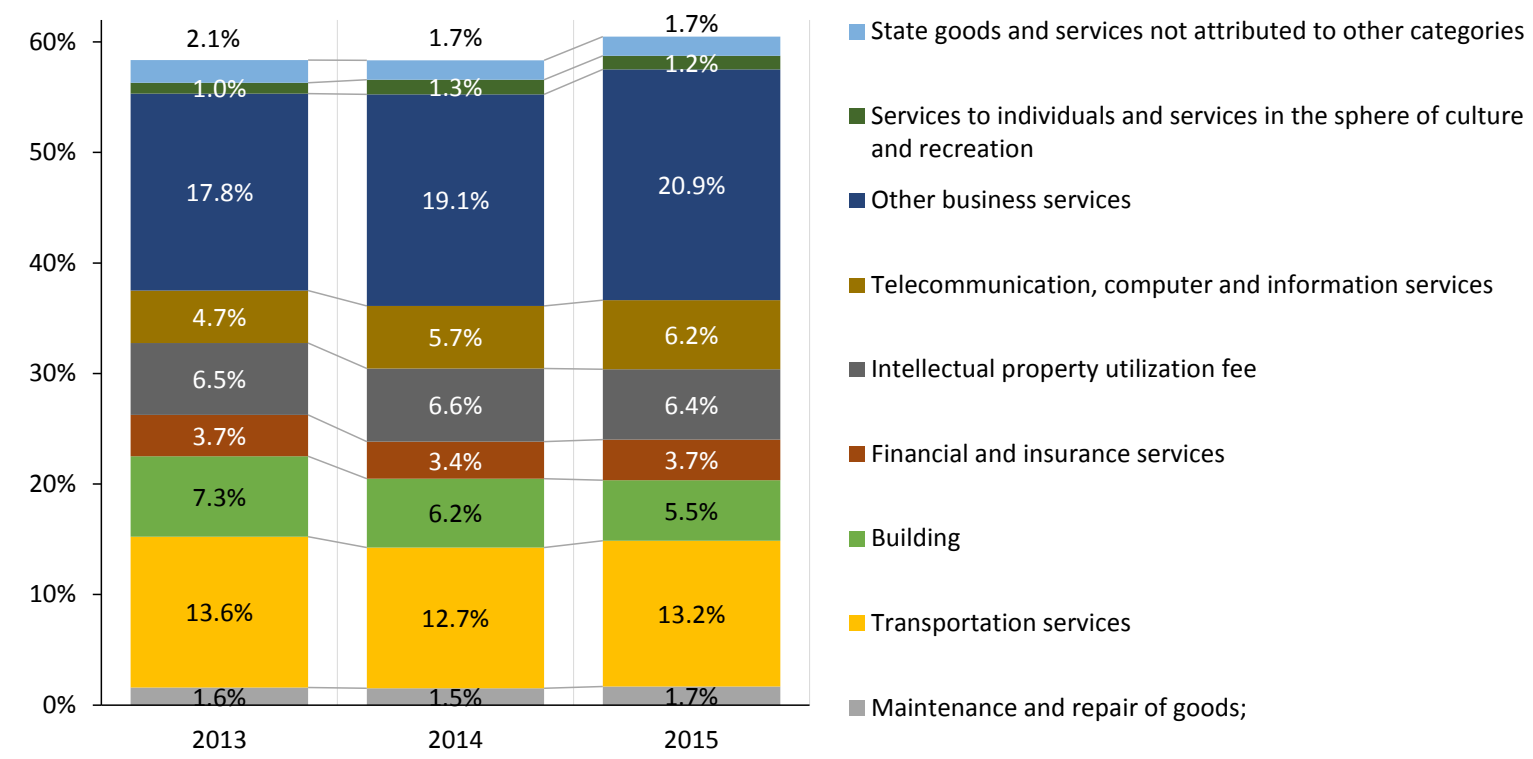

Source: The authors' calculations on the basis of the data of the Central Bank of Russia.

Fig. 2. The pattern of Russia's imports of services in the 2013-2015 Period, \%

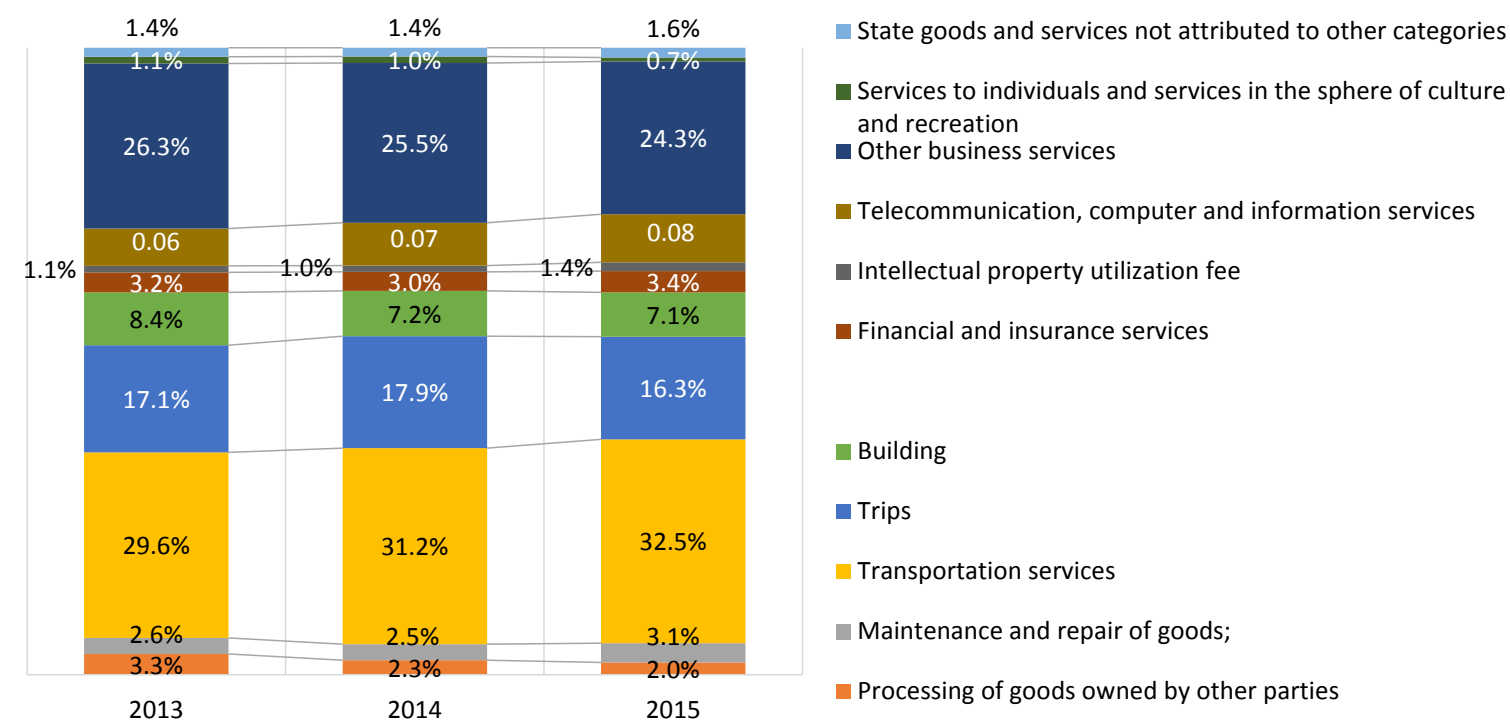

Source: The authors' calculations on the basis of the data of the Central Bank of Russia.

Fig. 3. The pattern of Russia's exports of services in the 2013-2015 period, \%

$17.8 \%$ to $20.9 \%$. Changes in shares of other large services sectors are shown in Fig. 2.

Dynamics of exports of different large services sectors was negative and irregular, too. In 2015, a drop amounted to $2 \%-56 \%$ as compared to 2013 . The smallest drop in exports (4.6\%) took place in the "telecommunication, computer and information services" sector, too, whose share rose from $5.9 \%$ in 2013 to $7.7 \%$ in 2015 . The largest drop (56.0\%) was registered in the "services related to processing of goods owned by other parties" sector. The "transportation services" sector which is the largest one as regards export volumes fell by $18.9 \%$ in 2015 as compared to 2013 and amounted to $\$ 16.8 \mathrm{bn}$, while its share rose from $29.6 \%$ in 2013 to $32.5 \%$ in 2015 . Changes in shares of other large services sectors are shown in Fig. 3. 


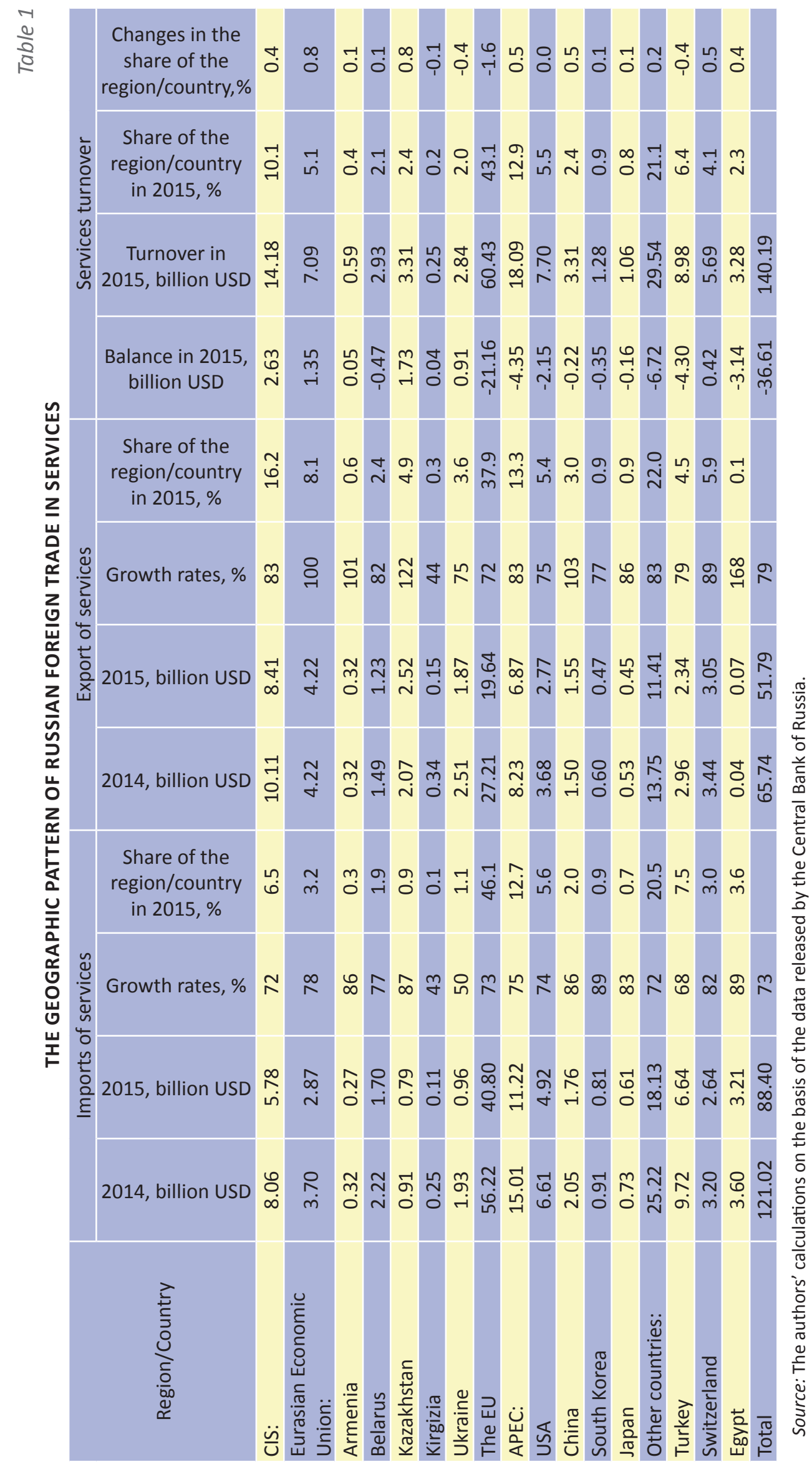


The geographic pattern of Russia's foreign trade in services with main partners (whose each share is over $1.5 \%$ of the volume of foreign trade in services) is shown in Table 1. In 2015, the share of the Eurasian Economic Union rose to $5.06 \%$ from $4.24 \%$ a year before mainly due to a $22 \%$ growth in exports of services to Kazakhstan. Insignificant growth in the shares of Belarus and Armenia was related to the fact that a drop in trade in services with those two countries in 2015 was somewhat lower than the decrease in the aggregate trade volume of services with other counties. A more than two-fold drop in services turnover with Kirgizia due to insignificant values of the bilateral trade in services did not affect much Russia's total trade in services with the Eurasian Economic Union.

A drop in Russia's exports of services to Ukraine (-25\%) was comparable with the average value (-21\%), while a drop in Russia's imports of services $(-50 \%)$ was much higher than the average value $(-27 \%)$. As a result, there was a dramatic drop in Ukraine's share in the foreign trade in services.

As in case of trade in goods ${ }^{1}$, the European Union is Russia's important partner as regards trade in services (its share in imports and exports of services amounts to $46 \%$ and $38 \%$, respectively). In 2015 , the trade in services with the EU fell to $\$ 60.4 \mathrm{bn}$, that is, by $28 \%$ as compared to 2014 . It is to be noted that a drop in the trade turnover took place with all the EU countries, except for Romania (+5\%). There was a more than twofold drop in trade in services with the EU's countries popular with holidaymakers, such as Greece $(-46 \%)$, Spain $(-43 \%)$, Finland $(-38 \%)$, Croatia $(-48 \%)$, the Czech Republic $(-45 \%)$ and Portugal (-48\%).

From among the APEC countries, the shares of the US, South Korea and Japan did not undergo serious changes, while the share of China rose by 0.5 p.p. to $2.4 \%$ of Russia's total turnover of services, though the volume of bilateral trade in services with China fell by $7 \%$.

As regards Russia's other prominent partners in trade in services, it is worth mentioning a 0.5 p.p. growth in the share of Switzerland due to less dramatic reduction of imports and exports of services to that country. A 0.4 p.p. decrease in Turkey's share to $6.4 \%$ was caused primarily by reduction of imports of services, while, on the contrary, a 0.4 p.p. growth in the share of Egypt to $2.3 \%$, to a less dramatic drop in imports of services.

1 A. Knobel and A. Firanchyuk. Russia's Output and Foreign Trade Dynamics. Russian Economic Developments. 2016, No. 4, pp. 27-32. 